\title{
Intestinal Absorption of Sucrose in Man: Interrelation of Hydrolysis and Monosaccharide Product Absorption *
}

\author{
Gary M. Gray † and Franz J. Ingelfinger \\ (From the Evans Memorial Department of Clinical Research, University Hospital, and the \\ Department of Medicine, Boston University School of Medicine, Boston University \\ Medical Center, Boston, Mass.)
}

Disaccharides are hydrolyzed by their specific enzymes present in the intestinal mucosa $(1-3)$. Although some current textbooks still state that these enzymes are secreted into the intestinal lumen (4-7), the concentrations of monosaccharide products free in intestinal contents during disaccharide absorption in vitro $(8-10)$ have been found insufficient to support the concept of intraluminal hydrolysis. In addition, the low disaccharidase activity of intestinal contents during the absorption process in vivo (11-13) strongly suggests that the disaccharide either enters the cell before being hydrolyzed or else is hydrolyzed at the cell surface by mucosa-bound enzyme. The released monosaccharide products presumedly are then transported across the intestinal cell $(8,14,15)$.

Little information is available that relates disaccharide hydrolysis to absorption of the component monosaccharides. Wilson and Vincent (14) commented on the accumulation of monosaccharides in the mucosal medium during the process of disaccharide absorption in hamster gut sac preparations, and Dahlqvist and Thomson have reported that large amounts of free fructose accumulate intraluminally during sucrose absorption in the intact rat (16). Despite these findings in animals, Dahlqvist and Borgström found little free intraluminal monosaccharides during the process of disaccharide absorption in man (12). It was recently demonstrated, however, that appreciable

* Submitted for publication June 10, 1965; accepted December 2, 1965.

Supported in part by U. S. Public Health Service research grant $A M \quad 03560-04$ and 05 and by training grant T1 AM 5025-07 and 08 from the National Institute of Arthritis and Metabolic Diseases.

Presented in part at the Annual Meeting of the American Society for Clinical Investigation, Atlantic City, N. J., May 3, 1964.

$\dagger$ Address requests for reprints to Dr. Gary M. Gray, U. S. Army Tropical Research Medical Laboratory, APO, New York, N. Y. 09851. amounts of the hydrolysis products accumulate intraluminally during the process of sucrose absorption in man and that these monosaccharides appear to move back from their mucosal site of hydrolysis to the lumen (13).

The present work is concerned with the relation of hydrolysis of sucrose to the absorption of its monosaccharide components, glucose, an actively absorbed monosaccharide $(14,15,17)$, and fructose, which is passively absorbed $(14,15)$.

\section{Methods}

Thirty-two normal young subjects were studied on 105 occasions by use of a double-lumen tube placed at various levels of the intestine $(13,18)$. Polyethlene glycol 4000 (PEG) was used as the nonabsorbable water-soluble marker and was determined by a modification of Hydén's method (19). Sucrose solution or an equivalent mixture of glucose and fructose made isotonic with $\mathrm{NaCl}$ $(290 \pm 10 \mathrm{mOsm}$ per L) was infused at $15 \mathrm{ml}$ per minute through the proximal orifice of the tube. In some studies, galactose was also infused. Intestinal samples were collected by siphonage from the distal orifice, which was located 15 or $30 \mathrm{~cm}$ from the site of infusion. The initial 30 minutes of an infusion period allowed steady state conditions to be approached so that, thereafter, concentration of PEG and the test sugar or sugars in successively collected samples showed little variation (13). When successive experiments were performed in the same intestinal segment, the equilibration period also served to prevent the contamination of one test by the residuals of a preceding test. Absorption rates determined by infusing a specific solution changed little (mean $\pm 10 \%$ ) when experiments were repeated during the course of a 10-hour period; thus there was no evidence of "fatigue" of the intestinal segment under study, and absorption of different carbohydrate solutions could be compared. The test solutions were infused in random order, and specimens obtained from the distal orifice were collected by use of the precautions previously outlined in order to insure stability of the carbohydrates (13).

Assay of carbohydrates in intestinal samples. After $\mathrm{Ba}(\mathrm{OH})_{2}-\mathrm{ZnSO}_{4}$ deproteinization $(20)$, sucrose, ${ }^{1}$ glu-

\footnotetext{
$1 \alpha-D$-Glucopyranosyl- $\beta$-D-fructofuranoside, analytical grade, Merck Co., Rahway, N. J.
} 
cose, $^{2}$ and total hexose (glucose plus fructose) 3 were determined by the specific enzymatic methods previously described (13). Glucose was substracted from total hexose to determine fructose.

In some of the samples containing only fructose and glucose, fructose was analyzed by Dische and Devi's ketohexose method (21); values obtained were within $3 \%$ of those found by use of the enzymatic method.

Galactose was assayed by a modification of the galactose oxidase assay described by Avigad, Amaral, Asensio, and Horecker (22). The reagent consisted of $125 \mathrm{U}$ galactose oxidase, ${ }^{5} 3 \mathrm{mg}$ peroxidase, ${ }^{6} 0.6 \mathrm{ml}$ of $1 \%$ o-dianisidine in $95 \%$ ethanol, $100,000 \mathrm{U}$ catalase, ${ }^{5}$ and 65 $\mathrm{ml}$ of $0.5 \mathrm{M}$ Tris buffer (23) at $\mathrm{pH}$ 7.0. It was necessary to prepare the reagent daily since the chromogen rapidly became colored. To $1 \mathrm{ml}$ of deproteinized sample $2.5 \mathrm{ml}$ of the reagent was added. The reaction mixture was incubated at $37^{\circ} \mathrm{C}$ for 20 minutes and the reaction stopped with $0.1 \mathrm{ml}$ of $1 \mathrm{~N} \mathrm{H}_{2} \mathrm{SO}_{4}$. Extinction was determined in a spectrophotometer at $395 \mathrm{~m} \mu$ and a 1-cm light path used. A linear relationship of optical density to concentration occurred when 50 to $125 \mu \mathrm{g}$ of galactose was in the cuvette. Amounts of galactose less than 50 $\mu \mathrm{g}$ produced little absorbance. Sucrose, glucose, and fructose in 25 times the concentration of galactose read the same as the reagent blank and did not interfere with the reaction. Recovery of galactose added to intestinal contents was $100 \pm 4 \%$.

Calculations. Sucrose disappearance over the intestinal segment may be considered as equal to the sucrose hydrolyzed, since appreciable amounts of sucrose do not disappear by absorption into blood of the intact disaccharide; this was discussed in a previous report (13). Considerable quantities of the monosaccharide hydrolysis products of sucrose accumulate intraluminally during the absorption process, and therefore amounts of the monosaccharide found at the collecting orifice must be subtracted from the sucrose hydrolyzed (sucrose that disappeared) to determine absorption (13).

Sucrose hydrolysis $=2\left[S_{1} \cdot V-S_{e} \cdot V \cdot\left(P_{1} / P_{c}\right)\right]$, and [1] sucrose absorption $=2\left[S_{1} \cdot V-S_{e} \cdot V \cdot\left(P_{1} / P_{e}\right)\right]$

$$
-\left[\left(G_{e}+F_{e}\right) V \cdot\left(P_{1} / P_{e}\right)\right],[2]
$$

where hydrolysis and absorption are expressed as millimoles monosaccharide per hour, and symbols refer to millimolar concentrations as follows: $S_{1}=$ sucrose in infusion; $S_{c}=$ sucrose in collected samples; $P_{1}=P E G$ in infusion; $P_{c}=P E G$ in collected samples; $G_{e}=$ glucose in collected samples; $F_{c}=$ fructose in collected samples. $\mathrm{V}=$ volume (liters infused in 1 hour).

2 D-Glucose, analytical grade, Merck Co., Rahway, N. J.

3.D-Fructose, C. P. Pfanstiehl Co., Waukegan, Ill.

4 D-Galactose, C. P. Pfanstiehl Co., Waukegan, Ill. Although all other carbohydrates used were chromatographically pure (less than $1 \%$ impurity), D-galactose contained $5 \%$ D-glucose (as measured by glucose oxidase and hexokinase reagents) and a trace of an oligosaccharide.

5 Worthington Biochemical Corp., Freehold, N. J.

- Nutritional Biochemicals Corp., Cleveland, Ohio.
Sucrose absorption can also be expressed in terms of the individual monosaccharides:

$$
\begin{aligned}
& \text { Glucose product absorption } \\
& \quad=\left[S_{1} \cdot V-S_{e} \cdot V \cdot\left(P_{1} / P_{c}\right)\right]-\left[G_{e} \cdot V \cdot\left(P_{1} / P_{c}\right)\right],
\end{aligned}
$$

and

fructose product absorption

$$
=\left[S_{1} \cdot V-S_{c} \cdot V \cdot\left(P_{1} / P_{c}\right)\right]-\left[F_{c} \cdot V \cdot\left(P_{1} / P_{c}\right)\right] .[4]
$$

The use of Equations 3 and 4 is necessary if absorption of sucrose is to be compared with that of an equivalent glucose-fructose mixture.

\section{Results}

Comparison of absorption of sucrose versus glucose-fructose mixture. To investigate the relation between the hydrolysis of the disaccharide and transport of its monosaccharides, we undertook paired experiments comparing absorption from sucrose $(73 \mathrm{mM})$ with that from an equivalent mixture containing glucose plus fructose $(73 \mathrm{mM}$ each monosaccharide). Experiments at a given intestinal level were performed over successive 60 -minute intervals and the solutions infused in random order. A $30-\mathrm{cm}$ distance between infusion orifice and collection orifice was used. As shown in Table I, glucose and fructose absorption rates were not significantly different whether the disaccharide was infused (mean: glucose, 35 mmoles per hour; fructose, 21 mmoles per hour) or the monosaccharide mixture was infused (mean: glucose, 39 mmoles per hour; fructose, 25 mmoles per hour). Also, a similar relation prevailed in 13 paired studies when $29 \mathrm{mM}$ sugars were infused. This is summarized in Table II.

Figure 1 relates glucose absorption rates in individual paired experiments and demonstrates that there is close correlation to linearity $(r=0.87$, $\mathrm{p}<0.001$ ) as well as to the theoretical line representing identical absorption from either infusion solution. A significant correlation, but of somewhat lower order, was also found for fructose absorption ( $r=0.62, p<0.01$ ) (Figure 2).

Effect of galactose on sucrose hydrolysis and absorption. In our experiments the rate of sucrose hydrolysis was greatly different in jejunum and ileum (Table I) (13). Despite this, similar amounts of monosaccharide products accumulated at all levels of intestine (Figure 3), suggesting the possibility that the hydrolytic process was inhibited in both jejunum and ileum once the intraluminal concentration of monosaccharides reached a criti- 
TABLE I

Comparison of absorption rates of sucrose with equimolar mixture of glucose plus fructose*

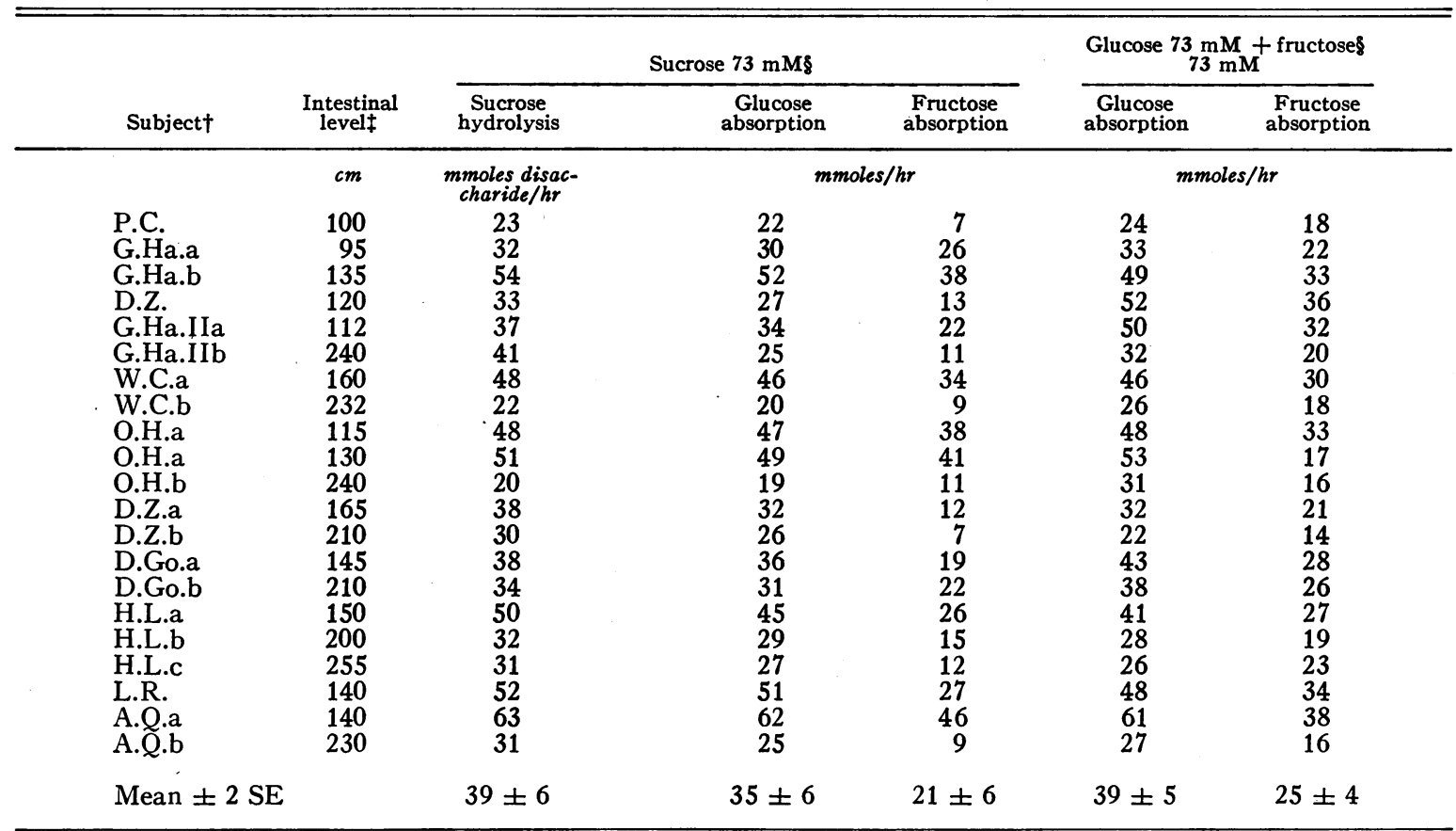

* Thirty-cm tube distance from infusion to collection orifice.

$\dagger$ Roman numerals after subjects' initials refer to a second study session 4 or more weeks after the initial experiment, and letters indicate first (a), second (b), or third (c) day of a study session.

$\ddagger$ Centimeters from incisor teeth to collecting orifice: 110 to $170 \mathrm{~cm}=$ jejunum; 170 to $260 \mathrm{~cm}=\mathrm{ileum}$.

$\$$ Glucose and fructose absorption not significantly different whether disaccharide or monosaccharide mixture infused $(p>0.3)$.

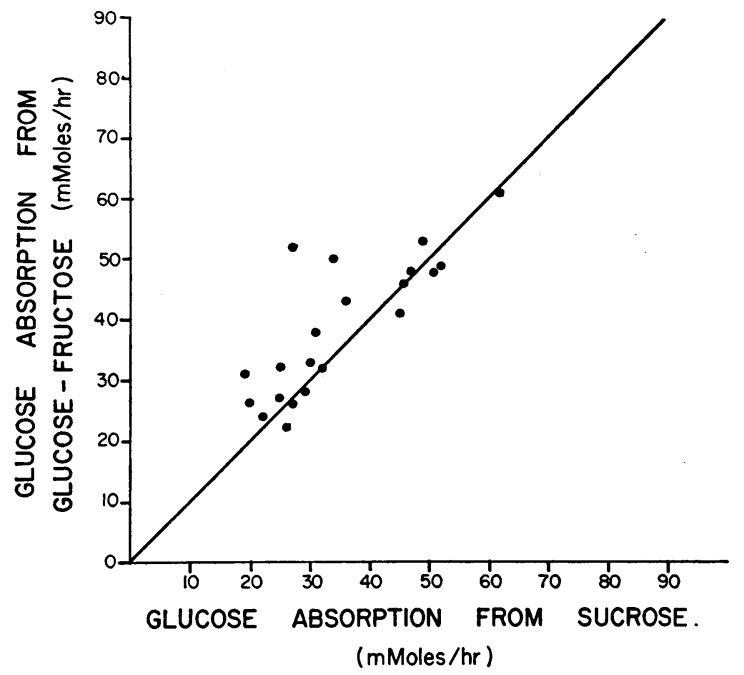

Fig. 1. CoRrelation OF GLUCOSE ABSORPTION FROM SUCROSE (73 MM) WITH ABSORPTION FROM AN EQUIVALENT MONOSACCHARIDE MIXTURE CONTAINING GLUCOSE (73 MM) AND FRUCTOSE (73 $\mathrm{mM})(\mathrm{r}=.87, \mathrm{p}<0.001)$. Each plot represents results of a paired experiment in a single subject, as related to the theoretical line representing equal absorption from each solution. cal level. Preliminary experiments comparing the effect of added glucose and fructose on hydrolysis rates of sucrose by use of the $30-\mathrm{cm}$ infusion-tocollection distance did not show definite inhibition, and the added glucose made it impossible to determine glucose product absorption from the sucrose. Further, these $30-\mathrm{cm}$ segment studies showed very efficient hydrolysis (greater than $80 \%$ ) when sucrose $(29 \mathrm{mM})$ alone was infused, and it was possible that the intestine's maximal capacity was not really being determined. If this were the case, inhibition by the added monosac-

TABLE II

Comparison of sucrose to glucose-fructose in 29 mM studies*

\begin{tabular}{|c|c|c|c|c|}
\hline \multirow[b]{2}{*}{$\begin{array}{l}\text { No. of } \\
\text { studies }\end{array}$} & \multicolumn{2}{|c|}{ Sucrose } & \multicolumn{2}{|c|}{ Glucose +fructose } \\
\hline & $\begin{array}{c}\text { Glucose } \\
\text { absorption }\end{array}$ & $\begin{array}{c}\text { Fructose } \\
\text { absorption }\end{array}$ & $\begin{array}{c}\text { Glucose } \\
\text { absorption }\end{array}$ & $\begin{array}{c}\text { Fructose } \\
\text { absorption }\end{array}$ \\
\hline & \multicolumn{2}{|c|}{ mmoles/hr } & \multicolumn{2}{|c|}{ mmoles/hr } \\
\hline 13 & $19 \pm 2$ & $11 \pm 3$ & $22 \pm 2$ & $11 \pm 2$ \\
\hline
\end{tabular}

*A 30-cm segment was used. Values expressed as mean $\pm 2 \mathrm{SE}$. 


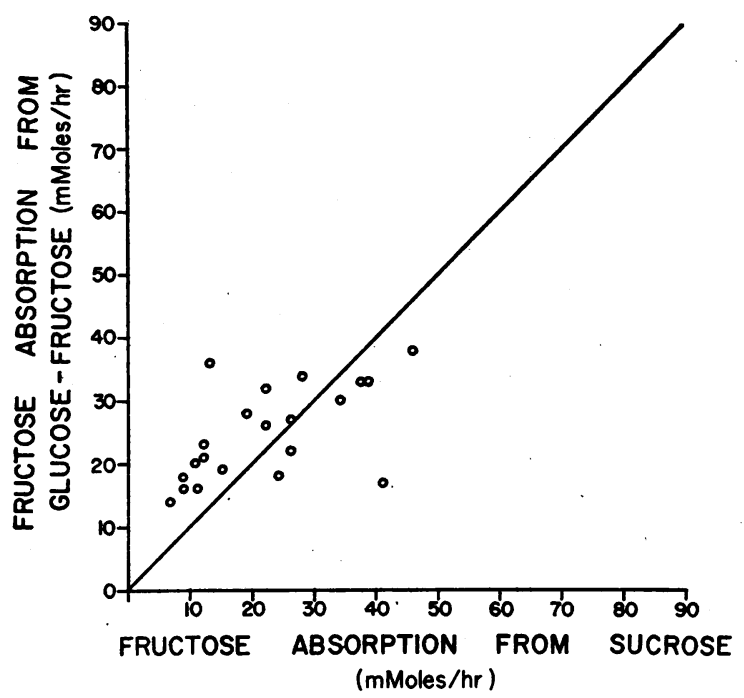

Fig. 2. Correlation of tructose absorption in the SAME MANNER AS IN FIgURE $4(r=.62, p<0.001)$.

charides might have been compensated for by the reserve hydrolytic activity of the intestine. Therefore a shorter intestinal segment $(15 \mathrm{~cm})$ was perfused, and galactose was substituted for glucose as a possible inhibitor, for galactose has a chemical structure closely related to glucose and makes. use of the same mechanism for active transport across intestinal mucosa $(14,15,24-27)$.

Paired experiments demonstrated that hydrolysis rates of sucrose were $20 \%$ lower when galactose was in the test solution than when sucrose was the sole sugar (Table III). The differences are statistically significant (paired analysis, $t$ test, $\mathrm{p}<0.02$ ). Glucose product absorption was also

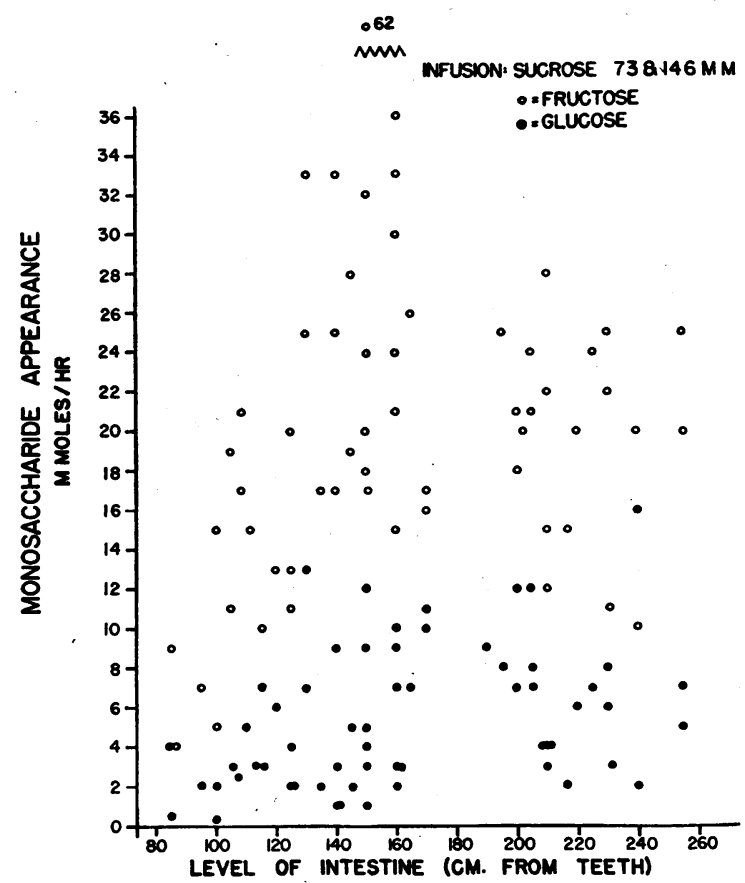

Fig. 3. Intraluminal accumulation of monosacCHARIDES DURING SUCROSE ABSORPTION AS RELATED TO INTESTINAL SITE. Both $73 \mathrm{mM}$ and $146 \mathrm{mM}$ studies are grouped, since values were not significantly different.

decreased $(p<0.02)$, but fructose product absorption did not change $(\mathrm{p}>0.2)$.

Effect of infusion concentration on absorption rates. The process of active absorption of glucose and galactose in animal preparations appears to conform to Michaelis-Menten kinetics $(15,25$, 28 ), and some information concerning the kinetics of glucose absorption in man has been recently

TABLE III

Effect of galactose on sucrose hydrolysis and absorption*

\begin{tabular}{|c|c|c|c|c|c|c|c|c|c|c|}
\hline \multirow{3}{*}{ Subject† } & \multirow{3}{*}{$\frac{\begin{array}{c}\text { Intestinal } \\
\text { level } \dagger\end{array}}{\mathrm{cm}}$} & \multicolumn{3}{|c|}{ Sucrose $40 \mathrm{mM}$} & \multicolumn{6}{|c|}{ Sucrose $40 \mathrm{mM}+$ galactose $40 \mathrm{mM}$} \\
\hline & & \multirow{2}{*}{$\frac{\text { Hydrolysis }}{\begin{array}{c}\text { mmoles } \\
\text { disac- } \\
\text { charide/hr }\end{array}}$} & $\begin{array}{c}\text { Glucose } \\
\text { absorp- } \\
\text { tion }\end{array}$ & $\begin{array}{c}\text { Fructose } \\
\text { absorp- } \\
\text { tion }\end{array}$ & \multicolumn{2}{|c|}{ Hydrolysis } & \multicolumn{2}{|c|}{$\begin{array}{l}\text { Glucose ab- } \\
\text { sorptionf }\end{array}$} & $\begin{array}{c}\text { Fructose } \\
\text { absorp- } \\
\text { tion }\end{array}$ & $\begin{array}{l}\text { Galactose } \\
\text { absorp- } \\
\text { tion }\end{array}$ \\
\hline & & & \multicolumn{2}{|c|}{ mmoles/hr. } & $\begin{array}{c}\text { mmoles } \\
\text { disac- } \\
\text { charide/hr }\end{array}$ & $\% \Delta$ & mmoles/hr & $\% \Delta$ & \multicolumn{2}{|c|}{ mmoles/hr } \\
\hline $\begin{array}{l}\text { D.Go.IIa } \\
\text { D.Go.IIb } \\
\text { V.W.W. } \\
\text { J.C.a } \\
\text { J.C.b } \\
\text { A.B.a } \\
\text { A.B.b }\end{array}$ & $\begin{array}{l}105 \\
210 \\
130 \\
145 \\
220 \\
160 \\
250\end{array}$ & $\begin{array}{l}25 \\
12 \\
26 \\
26 \\
9.0 \\
13 \\
27\end{array}$ & $\begin{array}{l}20 \\
10 \\
23 \\
23 \\
8.5 \\
12 \\
21\end{array}$ & $\begin{array}{c}21 \\
3.7 \\
13 \\
17 \\
5.8 \\
3.4 \\
8\end{array}$ & $\begin{array}{l}18 \\
11 \\
22 \\
22 \\
7.9 \\
10 \\
17\end{array}$ & $\begin{array}{l}-28 \\
=8 \\
-15 \\
=15 \\
-12 \\
=23 \\
-37\end{array}$ & $\begin{array}{c}16 \\
7.6 \\
20 \\
19 \\
6.5 \\
6.4 \\
13\end{array}$ & $\begin{array}{l}-20 \\
-24 \\
-13 \\
-17 \\
-24 \\
-47 \\
-38\end{array}$ & $\begin{array}{c}14 \\
6.0 \\
8.0 \\
17 \\
5.6 \\
4.3 \\
8\end{array}$ & $\begin{array}{c}16 \\
9.5 \\
8.5 \\
15 \\
10 \\
7.0 \\
10\end{array}$ \\
\hline Mean & & 20 & 17 & 118 & 15 & -20 & 13 & -20 & 98 & 11 \\
\hline
\end{tabular}

* Fifteen-cm tube distance from infusion to collection orifice.

t See Table I for explanation.

Foth sucrose hydrolysis and glucose absorption were significantly lower when galactose was in the infusion (paired analysis, $t$ test, $\mathrm{p}<0.02$ ).
Fructose absorption did not change significantly $(\mathrm{p}>0.2$ ).

8 Secimen lost; mean fructose values therefore based on six studies only. 


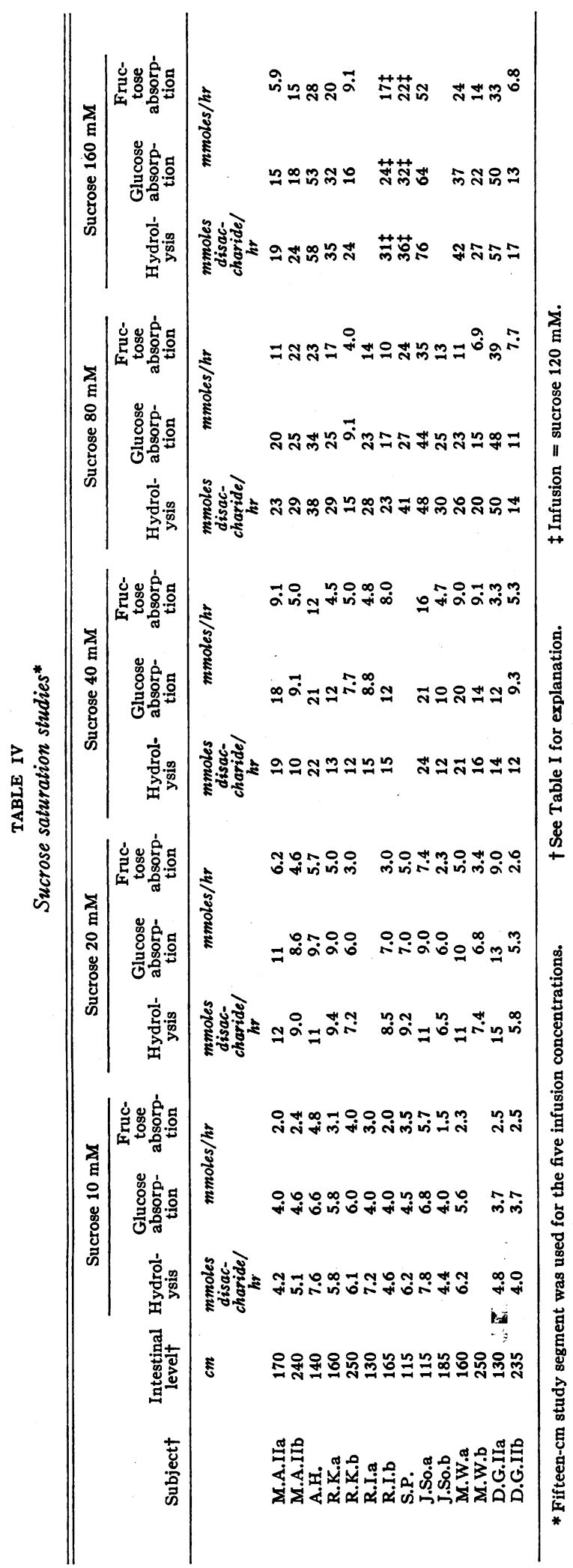

reported (29-31). To determine whether there is any kinetic relation of concentration of disaccharide to its rates of hydrolysis and absorption, we perfused solutions containing $10,20,40,80$, and $160 \mathrm{mM}$ sucrose through $15-\mathrm{cm}$ study segments. These solutions were given in random order to a subject over a single day. The relations obtained are shown in Table IV and representative data plotted in Figure 4. There appeared to be a limiting velocity for both hydrolysis and absorption in all experiments. Figure $\mathbf{5}$ shows the Lineweaver-Burk plot (32) for sucrose hydrolysis; there is no significant deviation from linearity (analysis of variance, $\mathrm{p}<0.001$ ). An almost identical curve can also be shown for glucose product absorption. The kinetics of these two processes are compared at different intestinal sites in Table V. Fructose product absorption conformed poorly to Michaelis-Menten kinetics and is not represented graphically.

\section{Discussion}

When the absorption of sucrose was considered in terms of its component monosaccharides, ${ }^{7}$ glucose was absorbed considerably more rapidly than fructose, and sucrose hydrolysis exceeded glucose absorption only slightly (Table I). Figure 6 diagrams what appears to occur during sucrose absorption in man, the mean results of infusing a 73 $\mathrm{mM}$ solution being shown. Of 66 mmoles of sucrose infused in 1 hour, 39 mmoles was hydrolyzed to the monosaccharide products. Of the 39 mmoles of glucose released, 35 was absorbed, whereas 4 was present or accumulated in the in-

7 Estimation of the sucrose absorption process in these terms depends upon the assumption that each molecule of sucrose is split by sucrase to one molecule of glucose and one of fructose. As well as having hydrolytic activity, all sucrases that have been purified thus far also have been found to catalyze the formation of small amounts of oligosaccharides when another sugar, rather than water, is used as a receptor (33-35). With mammalian sucrase, this transglycosylation process may cause a net release of smaller amounts of free glucose than fructose (36). Table VI demonstrates that such sucrase activity as there is in intestinal contents results in release of essentially equal amounts of glucose and fructose. Furthermore, analysis of collected intestinal samples by paper chromatography revealed no sugars other than sucrose, glucose, and fructose. Thus sucrose is split to essentially equal amounts of glucose and fructose under the conditions of our study. 

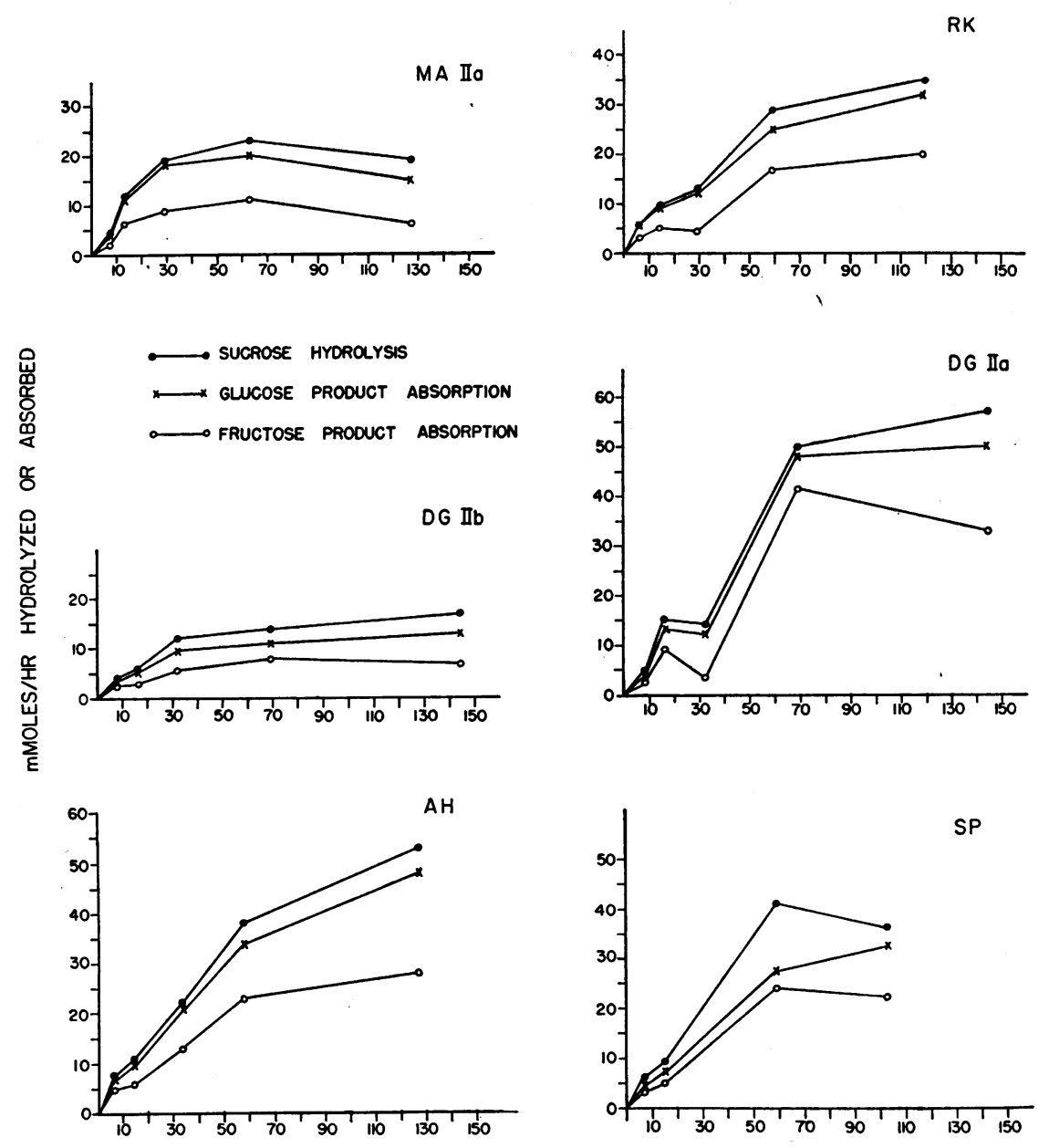

MEAN INTRALUMINAL SUCROSE (mMolar)

Fig. 4. RELATION OF MEAN INTRALUMinal SUCROSE CONCENTRATION TO HYDROLYSIS OF SUCROSE AND ABSORPTION RATES OF ITS GLUCOSE AND FRUCTOSE PRODUCTS. A $15-\mathrm{cm}$ test segment was used.

traluminal contents. In contrast, of the 39 mmoles of fructose released, only 21 was absorbed, and 18 accumulated intraluminally. Thus, nearly half of the fructose released from hydrolysis of sucrose was still present intraluminally at the point of the collection orifice. This reflects the slow absorption rate of fructose as compared to glucose (14, $17,31,37)$. These values for glucose and fructose accumulation are minimal values, since absorption of released monosaccharides presumably occurs over the whole length of the segment under study.

The magnitude of this intraluminal accumulation of monosaccharides is interesting in view of the current belief that the disaccharides enter the intestinal cell before being hydrolyzed $(1,9,10$, $12,16,38-41)$. Eichholz and Crane have recently localized sucrase to the plasma-membrane of the microvillus (42), and Crane has set up a hypothetical model for intestinal transport of sugars in which hydrolysis of disaccharides occurs within the outer portion of brush border plasma-membrane whereas the released monosaccharides are transported across a permeability barrier located deeper in the cell, in the inner portion of the same membrane (43). Transport across this barrier presumedly requires utilization of a carrier mechanism $(15,44,45)$, since carbohydrates have a 


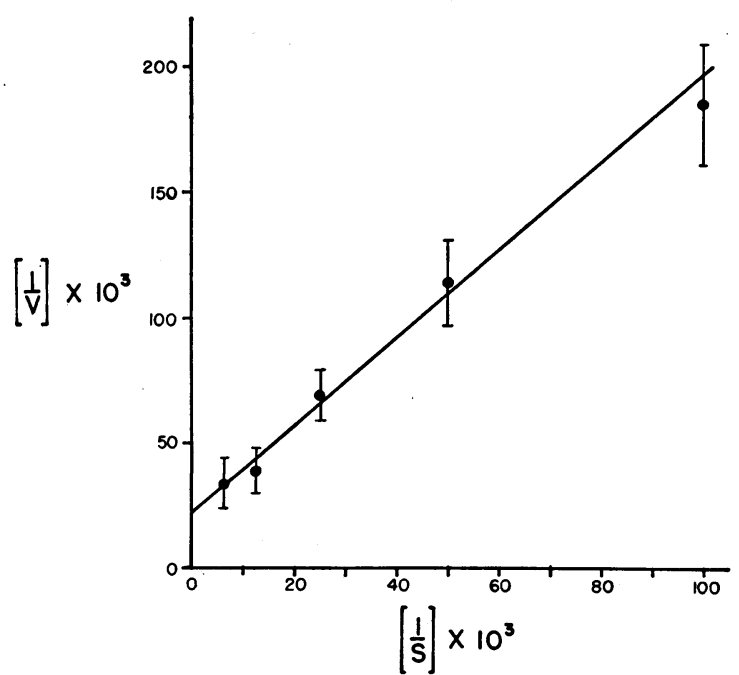

Fig. 5. LINEWEAVER-BURK PLOT FOR SUCROSE HYDROLYsis. Values are calculated from Table IV and expressed as mean $\pm 2 \mathrm{SE}$. Units for $\mathrm{S}$ (substrate concentration) and V (rate of hydrolysis) are millimoles per liter and millimoles per hour, respectively. The correlation with linearity is significant (analysis of variance, $\mathrm{p}<0.001$ ).

hydrated molecular diameter larger than the calculated pore size of the permeability barrier and hence cannot cross it by simple diffusion $(46,47)$. Our findings of large amounts of monosaccharide products within the lumen are consistent with Crane's hypothesis, since the disaccharide could be split in the outer brush border and some of the released monosaccharides could then move back into the lumen by diffusion without crossing a permeability barrier. However, the exact location of this barrier in the intestinal cell is uncertain, and it may well be located at the outermost portion of the cell, i.e., at the limiting plasma-membrane of the microvillus. If this were the case, intracellular hydrolysis would result in an inefficient disac-

TABLE V

Kinetic data from sucrose saturation studies*

\begin{tabular}{|c|c|c|c|c|c|}
\hline \multirow{2}{*}{$\begin{array}{l}\text { No. of } \\
\text { studies }\end{array}$} & \multirow{2}{*}{$\begin{array}{l}\text { Intestinal } \\
\text { site }\end{array}$} & \multicolumn{2}{|c|}{$\begin{array}{c}\text { Sucrose } \\
\text { hydrolysis }\end{array}$} & \multicolumn{2}{|c|}{$\begin{array}{l}\text { Glucose prod- } \\
\text { uct absorption }\end{array}$} \\
\hline & & $\overline{\max }$ & $\overline{\mathrm{Km}}$ & $\overline{\max }$ & $\overline{\mathrm{Km}}$ \\
\hline & & $\begin{array}{c}\text { mmoles/ } \\
\text { hr/ } \\
15-\mathrm{cm} \\
\text { segment }\end{array}$ & $\underset{L}{\text { mmoles/ }}$ & $\begin{array}{c}\text { mmoles/ } \\
h r / \\
15-c m \\
\text { segment }\end{array}$ & $\underset{L}{\text { mmoles/ }}$ \\
\hline 8 & Jejunum & 83 & 142 & 83 & 154 \\
\hline 6 & Ileum & 36 & 74 & 25 & 50 \\
\hline
\end{tabular}

* Derived from data in Table IV. Vmax $=$ maximal velocity; $\mathrm{Km}$ = Michaelis constant.
TABLE VI

Comparison of amounts of monosaccharide released from sucrase activity of intestinal contents in vitro*

\begin{tabular}{cccc}
\hline \hline $\begin{array}{c}\text { Sample } \\
\text { no. }\end{array}$ & $\begin{array}{c}\text { Glucose } \\
\text { released }\end{array}$ & $\begin{array}{c}\text { Fructose } \\
\text { released }\end{array}$ & $\begin{array}{c}\text { Glucose/ } \\
\text { Fructose } \\
\text { ratio }\end{array}$ \\
\hline \multicolumn{4}{c}{$\begin{array}{c}\text { mmoles } / h r / L \text { in- } \\
\text { testinal } \\
\text { contents }\end{array}$} \\
A & 3 & 3 & 1.0 \\
B & 5 & 6 & 0.84 \\
C & 5 & 6 & 0.84 \\
D & 9 & 9 & 1.0 \\
E & 8 & 9 & 0.89 \\
F & 7 & 8 & 0.88 \\
G & 6 & 7 & 0.86 \\
H & 19 & 19 & 1.0 \\
I & 9 & 8 & 1.1 \\
\hline
\end{tabular}

* Incubation at $37^{\circ} \mathrm{C}$ for 1 hour in sucrose substrate.

charide absorption process because both entry of sucrose into the cell and subsequent exit of released glucose and fructose from the cell back into the lumen would require carrier-mediated transport across the permeability barrier. Thus, our results, although compatible with the intracellular hydrolysis hypothesis, are perhaps more consistent with the hypothesis that sucrose is hydrolyzed by brush border enzyme while the disaccharide is still within the lumen, especially if the intestinal permeability barrier were shown to be located at the limiting plasma-membrane of the cell.

The finding of equal absorption rates for sucrose and the monosaccharide mixture at two dif-

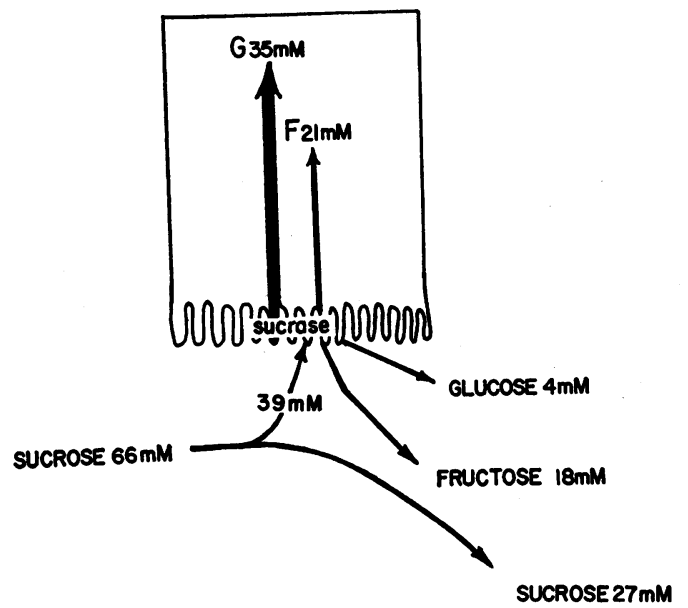

Fig. 6. SUCrose absorption IN HUMAN INTESTINAL PERFUSION EXPERIMENTS. A diagrammatic representation of what occurs over a $30-\mathrm{cm}$ segment of intestine when sucrose $(73 \mathrm{mM})$ is infused. Values refer to millimoles per hour. See text for elaboration. 
ferent infusion concentrations suggests that the hydrolytic step is not rate limiting in the over-all process of sucrose absorption. This is in accord with the in vitro guinea pig experiments of Fridhandler and Quastel (8) as well as with the work of Dahlqvist and Thomson, who fed sucrose and an equivalent glucose-fructose mixture to rats (16). It is tempting to conclude that the individual transport rates for glucose and fructose define the sucrose absorption process. However, little is known about the importance of local physical conditions in the absorption process, and it is conceivable that rate of contact between sugar molecules and mucosal surface may occur more slowly than either the hydrolytic or transport processes. Whether physical conditions are rate limiting in the over-all process of absorption cannot be determined from our experiments.

In these comparative studies, a measure of the dependence of absorption upon monosaccharide concentrations within the lumen is provided by determining the ratio of absorbed to intraluminal monosaccharide (Table VII). It is notable that sucrose has a marked advantage over the monosaccharide mixture since this ratio is three to six times greater for glucose and two times greater for fructose than that found for the monosaccharide mixture, indicating that absorption rates of the released glucose and fructose products do not depend on their concentrations within the luminal fluid. Instead, it is probable that a local high concentration, comparable to the luminal concentration of an equivalent monosaccharide mixture, is provided from splitting of sucrose at the brush border membrane and maintained for the transport mechanism at the outermost portion of the intestinal cell. This finding is analogous to the intracellular-medium ratios found by Miller and Crane in gut sac preparations (9). Unfortu-

TABLE VII

Ratio of absorbed to intraluminal monosaccharides*

\begin{tabular}{|c|c|c|c|c|c|}
\hline & \multirow{2}{*}{$\begin{array}{l}\text { Infusion } \\
\text { concen- } \\
\text { tration }\end{array}$} & \multicolumn{2}{|c|}{$\begin{array}{l}\text { Infusion: } \\
\text { sucrose }\end{array}$} & \multicolumn{2}{|c|}{$\begin{array}{l}\text { Infusion: } \\
\text { glucose } \\
\text { t fructose }\end{array}$} \\
\hline & & Glucose & Fructose & Glucose & Fructose \\
\hline & $29 \mathrm{mM}$ & 19 & 1.2 & 5.5 & 0.73 \\
\hline & $73 \mathrm{mM}$ & 8.8 & 1.2 & 1.4 & 0.61 \\
\hline
\end{tabular}

* Derived from mean values of paired studies (Tables I and II). nately, it does not distinguish intracellular hydrolysis from hydrolysis at the cell surface. If the disaccharide were split at the cell surface, there might be a high concentration of monosaccharide in the fluid immediately adjacent to the mucosal surface with a gradient of decreasing concentrations toward the center of the lumen. Analysis of the collected luminal fluid reveals only the mean intraluminal concentration.

The fact that the presence of galactose in the infusing solution appeared to cause an inhibition of sucrose hydrolysis (Table IV) must be interpreted with caution. Galactose competes with glucose for the active transport process (24-27), and hence any glucose displaced from this process by galactose might accumulate and inhibit sucrase, thereby retarding sucrose hydrolysis. It seems unlikely that the trace impurities of glucose or oligosaccharide in the galactose would have such a marked effect on sucrose hydrolysis. Apparently, then, sucrose hydrolysis in man may be inhibited in the presence of galactose by 1) galactose itself, 2) glucose released from sucrose and displaced from the active transport process by the galactose (product inhibition), or 3) feedback inhibition of sucrase by a saturated active transport mechanism that must transport the added galactose as well as glucose. The last hypothesis would require an intimate interrelation between disaccharide hydrolysis and the active transport process for glucose. Such a relation has indeed been suggested by Crane (43), and more recently by Semenza, Tosi, Vallotton-Delachaux, and Mülhaupt (48), who found that $\mathrm{Na}^{+}$is not only important for active glucose transport (49), but also activates sucrase.

When sucrose in 10 to $160 \mathrm{mM}$ concentrations was infused in $15-\mathrm{cm}$ segments, every study appeared to show hydrolysis and absorption rates that approached a maximum (Table IV, Figure 4 ), but the relation of these rates to mean intraluminal sucrose concentration varied from subject to subject. Sucrose hydrolysis and glucose product absorption did appear to conform reasonably well to Michaelis-Menten kinetics when mean values of the studies were plotted. Figure $5 \mathrm{dem}$ onstrates this for sucrose hydrolysis. A nearly identical relation prevailed for glucose product absorption, suggesting a close interrelation between hydrolysis of sucrose and absorption of the re- 
leased glucose. When jejunal and ileal studies were evaluated separately, values for the maximal velocity and the Michaelis constant were higher for jejunum than ileum (Table V). This probably indicates that jejunum has a greater capacity for absorption of sucrose at high concentrations of sugar, whereas the ileum performs quite efficiently at the low concentrations that still remain after the major portion has been absorbed from jejunum.

The restricted surface area used in intestinal perfusion experiments may result in saturation phenomena irrespective of the presence or absence of specific binding sites for hydrolysis or transport, and demonstration of a maximal rate is not, of itself, evidence for enzymatic hydrolysis or carrier-mediated transport. However, the apparent Michaelis constant for sucrose hydrolysis in these studies in man is remarkably close to that recently found by Dahlquist and Thomson for intact rabbit intestine in vitro (50). It is important to note that the kinetic relationships shown for the hydrolytic process should not be assumed to equal those for sucrase itself, since the geometric relations important for contact between sugar and enzyme are undoubtedly quite different for intact intestinal tissue as compared to a homogenate or purified tissue extract. Thus it has been shown that Michaelis constants for intact intestine are a full order of magnitude higher than those for homogenates (50).

\section{Summary}

1) Sucrose absorption was studied in man and expressed in terms of sucrose hydrolysis and absorption of its component monosaccharides, glucose and fructose.

2) Sucrose hydrolysis rates exceeded the monosaccharide product absorption rates, and the glucose component was absorbed considerably more rapidly than the fructose component. Moreover, paired experiments demonstrated the same absorption rates of these monosaccharides from sucrose as from an equivalent glucose-fructose mixture. Hence, hydrolysis does not appear to be rate limiting in the process of sucrose absorption, and the individual absorption rates for glucose and fructose may define the rate of the disaccharide absorption process.
3) Comparison of absorption from solutions having different concentrations of sucrose demonstrated the kinetic relationships to be variable from subject to subject, but Lineweaver-Burk plots revealed saturation kinetics that were nearly identical for sucrose hydrolysis and glucose product absorption, suggesting an interdependence of these two processes.

4) The addition of galactose to the sucrose solution infused caused an appreciable decrease in sucrose hydrolysis and glucose product absorption, but had no effect on fructose product absorption. Since galactose is known to compete with glucose for the active transport process, this suggests that intestinal sucrase is inhibited either by the glucose product or by a feedback inhibition by a saturated active transport mechanism.

\section{Acknowledgments}

The authors are grateful to Dr. Robert K. Crane for his interest and suggestions and to Mrs. Priscilla Taggart for technical assistance.

\section{References}

1. Miller, D., and R. K. Crane. The digestive function of the epithelium of the small intestine. II. Localization of disaccharide hydrolysis in the isolated brush border portion of intestinal epithelial cells. Biochim. biophys. Acta (Amst.) 1961, 52, 293.

2. Dahlqvist, A. Specificity of the human intestinal disaccharidases and implications for hereditary disaccharide intolerance. J. clin. Invest. 1962, 41, 463.

3. Auricchio, S., A. Rubino, R. Tosi, G. Semenza, M. Landolt, H. Kistler, and A. Prader. Disaccharidase activities in human intestinal mucosa. Enzymol. biol. clin. (Basel) 1963, 3, 193.

4. White, A., P. Handler, E. L. Smith, and D. W. Stetten. Principles of Biochemistry. New York, Blakiston, 1959, p. 381.

5. Thomas, J. E. Secretion and absorption in the intestine in The Physiologic Basis of Medical Practice, 7th ed., C. H. Best and N. B. Taylor, Eds. Baltimore, Williams \& Wilkins, 1961, p. 669.

6. Cantarow, A., and B. Schepartz. Biochemistry, 3rd ed. Philadelphia, W. B. Saunders, 1962, p. 270.

7. Hoffman, W. S. The biochemistry of clinical medicine, 3rd ed. Chicago, Year Book, 1964, p. 65.

8. Fridhandler, L., and J. H. Quastel. Absorption of sugars from isolated surviving intestine. Arch. Biochem. 1955, 56, 412.

9. Miller, D., and R. K. Crane. The digestive function of the epithelium of the small intestine. I. An 
intracellular locus of disaccharide and sugar phosphate ester hydrolysis. Biochim. biophys. Acta (Amst.) 1961, 52, 281.

10. Newey, H., P. A. Sanford, and D. H. Smyth. Location of function in the intestinal epithelial cell in relation to carbohydrate absorption. J. Physiol. (Lond.) 1963, 168, 423.

11. Cajori, F. A. The enzyme activity of dogs' intestinal juice and its relation to intestinal digestion. Amer. J. Physiol. 1933, 104, 659.

12. Dahlqvist, A., and B. Borgström. Digestion and absorption of disaccharides in man. Biochem. J. 1961, 81, 411.

13. Gray, G. M., and F. J. Ingelfinger. Intestinal absorption of sucrose in man: the site of hydrolysis and absorption. J. clin. Invest. 1965, 44, 390.

14. Wilson, T. H., and T. N. Vincent. Absorption of sugars in vitro by the intestine of the golden hamster. J. biol. Chem. 1955, 216, 851.

15. Crane, R. $\dot{K}$. Intestinal absorption of sugars. Physiol. Rev. 1960, 40, 789.

16. Dahlqvist, A., and D. L. Thomson. The digestion and absorption of sucrose by the intact rat. J. Physiol. (Lond.) 1963, 167, 193.

17. Fisher, R. B., and D. S. Parsons. Glucose movements across the wall of the rat small intestine. J. Physiol. (Lond.) 1953, 119, 210.

18. Fordtran, J. S., K. H. Soergel, and F. J. Ingelfinger. Intestinal absorption of $\mathrm{D}$-xylose in man. New Engl. J. Med. 1962, 267, 274.

19. Hydén, S. A turbidmetric method for the determination of higher polyethylene glycols in biologic materials. Ann. roy. agr. Coll. Sweden 1955, 22, 139.

20. Somogyi, M. Determination of blood sugar. J. biol. Chem. 1945, 160, 69.

21. Dische, Z., and A. Devi. A new colorimetric method for the determination of ketohexoses in presence of aldoses, ketoheptoses and ketopentoses. Biochim. biophys. Acta (Amst.) 1960, 39, 140.

22. Avigad, G., D. Amaral, C. Asensio, and B. L. Horecker. The D-galactose oxidase of Polyporus circinatus. J. biol. Chem. 1962, 237, 2736.

23. Dahlqvist, A. Determination of maltase and isomaltase activities with a glucose-oxidase reagent. Biochem. J. 1961, 80, 547.

24. Cori, C. F. The rate of absorption of a mixture of glucose and galactose. Proc. Soc. exp. Biol. (N. Y.) 1926, 23, 290.

25. Fisher, R. B., and D. S. Parsons. Galactose absorption from the surviving small intestine of the rat. J. Physiol. (Lond.) 1953, 119, 224.

26. Jorgensen, C. R., B. R. Landau, and T. H. Wilson. A common pathway for sugar transport in hamster intestine. Amer. J. Physiol. 1961, 200, 111.

27. Annegers, J. H. Intestinal absorption of hexose in the dog. Amer. J. Physiol. 1964, 206, 1095.

28. Crane, R. K. Studies on the mechanism of the intestinal absorption of sugars. III. Mutual in- hibition, in vitro, between some actively transported sugars. Biochim. biophys. Acta (Amst.) 1960, 45, 477.

29. Schedl, H. P., and J. A. Clifton. Kinetics of intestinal absorption in man: normal subjects and patients with sprue (abstract). J. clin. Invest. 1961, 40, 1079.

30. Schedl, H. P., and J. A. Clifton. Kinetics of intestinal absorption in man: normals and patients with sprue. Proceedings of the Second World Congress of Gastroenterology, Munich, 1962, II. 1963, 728.

31. Holdsworth, C. D., and A. M. Dawson. The absorption of monosaccharides in man. Clin. Sci. 1964, 27, 371.

32. Lineweaver, H., and D. Burk. The determination of enzyme dissociation constants. J. Amer. chem. Soc. 1934, 56, 658.

33. Bacon, J. S. D., and J. Edelman. The action of invertase preparations. Arch. Biochem. 1950, 28, 467.

34. Blanchard, P. H., and N. Albon. The inversion of sucrose; a complication. Arch. Biochem. 1950, $29,220$.

35. Edelman, J. The formation of oligosaccharides by enzymatic transglycosylation. Advanc. Enzymol. 1956, 17, 189.

36. Dahlqvist, A. "Substrate inhibition" of intestinal glycosidases. Acta chem. scand. 1960, 14, 1797.

37. Groen, J. The absorption of hexoses from the upper part of the small intestine in man. J. clin. Invest. 1937, 16, 245.

38. Miller, D., and R. K. Crane. The digestion of carbohydrates in the small intestine. Amer. J. clin. Nutr. 1963, 12, 220.

39. Prader, A., G. Semenza, and S. Auricchio. Intestinale Absorption und Malabsorption der Disaccharide. Schweiz. med. Wschr. 1963, 93, 1272.

40. Isselbacher, K. J., and J. R. Senior. The intestinal absorption of carbohydrate and fat. Gastroenterology 1964, 46, 287.

41. Sonntag, W. M., M. L. Brill, W. G. Troyer, Jr., J. D. Welsh, G. Semenza, and A. Prader. Sucroseisomaltose malabsorption in an adult woman. Gastroenterology 1964, 47, 18.

42. Eichholz, A., and R. K. Crane. Personal communication.

43. Crane, R. K. Hypothesis for mechanism of intestinal active transport of sugars. Fed. Proc. 1962, 21, 891.

44. Cirillo, V. P. Sugar transport in microorganisms. Ann. Rev. Microbiol. 1961, 15, 197.

45. Csáky, T. Z. Intestinal absorption: changing concepts and ideas. Gastroenterology 1964, 47, 201.

46. Solomon, A. K. Measurement of the equivalent pore radius in cell membranes in Membrane Transport and Metabolism, A. Kleinzeller and A. Kotyk, Eds. London and New York, Academic Press, 1961, p. 94. 
47. Lindemann, B., and A. K. Solomon. Permeability of luminal surface of intestinal mucosal cells. J. gen. Physiol. 1962, 45, 801.

48. Semenza, G., R. Tosi, M. C. Vallotton-Delachaux, and E. Mülhaupt. Sodium activation of human intestinal sucrase and its possible significance in the enzymatic organization of brush borders. Biochim. biophys. Acta (Amst.) 1964, 89, 109.
49. Riklis, E., and J. H. Quastel. Effects of cations on sugar absorption by isolated surviving guinea pig intestine. Canad. J. Biochem. 1958, 36, 347.

50. Dahlqvist, A., and D. L. Thomson. The hydrolysis of sucrose by intact and homogenized cells of rat small intestine. Influence of $\mathrm{pH}$ and substrate concentration. Biochim. biophys. Acta (Amst.) 1964, 92, 99. 